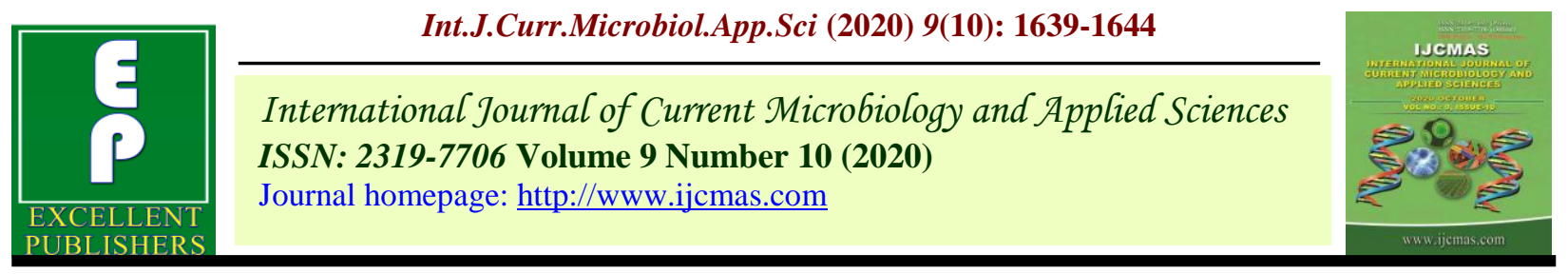

Original Research Article

https://doi.org/10.20546/ijcmas.2020.910.197

\title{
Effect of Zinc, Iron and their Methods of Application on Growth and Yield of Pearlmillet (Pennisetum glaucum L.)
}

\author{
Ramasahayam Uday Kumar Reddy*, Joy Dawson and D. R. M. S. Vidya Sagar \\ Department of Agronomy, Sam Higginbottom University of Agriculture, Technology and \\ Sciences, Prayagraj- 211007, Uttar Pradesh, India \\ *Corresponding author
}

\begin{abstract}
A B S T R A C T
Keywords

Pearlmillet, Zinc, Iron, Soil application, Foliar application

Article Info

Accepted: 12 September 2020 Available Online: 10 October 2020

\section{Introduction}

Pearlmillet occupies fourth position among cereals crops next to rice, wheat and sorghum. Pearlmillet may be an alternative crop that exhibits great advantages in physiological characteristics when compared to other cereals as it is drought resistant, high salinity and high temperature tolerance (Rai et al., 2008). Pearlmillet is the only cereal crop that is capable of producing a reliable yield under marginal environments and simultaneously responds to high management practices. It is high nutritionally better than many cereals as it is a good source of protein (12.6\%), Iron
\end{abstract}

The field experiment was conducted during Kharif 2019 at Central Crop Research Farm, Department of Agronomy, SHUATS, Prayagraj (U.P.) with the objective to study the effect of Zinc, Iron and their methods of application on growth and yield of Pearlmillet (Pennisetum glaucum L.) under Randomised block design comprising of 10 treatments of which soil application of zinc $(25 \mathrm{~kg} / \mathrm{ha})$ and iron $(10 \mathrm{~kg} / \mathrm{ha})$ at basal and foliar application of $0.5 \%$ of Zinc and iron at 35 and 55 days after sowing which are replicated thrice. The experimental results revealed maximum plant height $(156.31 \mathrm{~cm})$, dry weight $(49.23 \mathrm{~g})$, grain yield $(2327.37$ $\mathrm{kg} / \mathrm{ha})$, stover yield $(4584.86 \mathrm{~kg} / \mathrm{ha})$ and test weight $(7.63 \mathrm{~g})$ was obtained by the application of $\mathrm{T}_{9}\left(0.5 \% \mathrm{ZnSO}_{4}\right.$ and $\mathrm{FeSO}_{4}$ foliar spray at 35 and $\left.55 \mathrm{DAS}\right)$.
(2.8\%), zinc and fat (5\%) and it is also rich in various vitamins.

The importance of micronutrients has been realized during the past four decades when wide spread of micronutrient deficiencies particularly that of Zinc and iron were observed in most of the soils of the country. Micronutrients have not only cured nutritional disorder in plants but are also known to improve the yield and quality (Jakhar et al., 2006). Zinc being one of the essential micronutrient plays significant role in various enzymatic and physiological activities. It is required as a structural component of large 
number of proteins, such as transcription factors and metallo enzymes (Singh and Kumar, 2009).

Iron is a constituent of several enzymes and some pigments and assists in nitrate and sulphate reduction and energy production within the plant.Iron is also a structural component of porphyrin, cytochromes, ferrchrome. Iron in chloroplasts reflects the presence of cytochromes which is performing various photosynthetic reduction process.

Application of micronutrient fertilizers through soil application is the most efficient and economical method of getting these nutrients into the crops. The amount of nutrients required is much higher compared to foliar application. Foliar application is widely used to apply nutrients for many crops. The deficiency symptoms are usually corrected with in few days (Mortvedt, 2000).

\section{Materials and Methods}

The experiment was conducted during Kharif season 2019, at the Crop Research farm, Department of Agronomy, SHUATS, Prayagraj (U.P). The soil of the experimental plot was sandy loam in texture, nearly neutral in soil reaction (7.10), available $\mathrm{N}$ (171 $\mathrm{kg} / \mathrm{ha})$, available $\mathrm{P}(15.20 \mathrm{~kg} / \mathrm{ha})$, available $\mathrm{K}$ $(232.50 \mathrm{~kg} / \mathrm{ha})$. The treatment consists of soil application of zinc (25 kg/ha) and iron (10 $\mathrm{kg} / \mathrm{ha}$ ) as basal and foliar application of $0.5 \%$ $\mathrm{ZnSO}_{4}$ and $\mathrm{FeSO}_{4}$ at 35 and 55 days after sowing. There were 10 treatments each replicated thrice. The experiment was laid out in Randomised Block Design. The crop was sown on 23 July 2019 at a spacing of $45 \mathrm{~cm}^{*} 15 \mathrm{~cm}$. The recommended dose of 80 $\mathrm{kg} \mathrm{N}, 40 \mathrm{~kg} \mathrm{P}, 40 \mathrm{~kg} \mathrm{~K}$ per ha was applied according to treatment details through urea, DAP, MOP and zinc and iron applied as zinc sulphate and iron sulphate. The half dose of nitrogen and full dose of phosphorous, potassium, zinc and iron were applied as basal. The split dose of nitrogen applied at 50 days after sowing and foliar application of zinc and iron were done at 35 and 55 days after sowing a per treatment details. Five random plants were selected from each plot to record observations on plant growth attributes. Similarly, five random plant samples were collected from each plot at the time of harvest for recording observations on plant yield attributes. Experimental data collected was subjected to statistical analysis by adopting Fishers method of Analysis of Variance (ANOVA) as outlined by Gomez and Gomez (2010). Critical Difference (CD) value were calculated whenever the ' $F$ ' test was found significant at $5 \%$ level.

\section{Results and Discussion}

The growth parameters like plant height and dry weight was significantly affected by the different methods of application of zinc and iron at different stages were represented in Table 1.

\section{Plant height (cm)}

The Pearlmillet crop fertilized with $0.5 \%$ $\mathrm{ZnSO}_{4}$ and $\mathrm{FeSO}_{4}$ foliar spray at 35 and 55 DAS significantly resulted maximum plant height $(156.31 \mathrm{~cm})$ which was statistically at par with $0.5 \% \mathrm{ZnSO}_{4}$ and $\mathrm{FeSO}_{4}$ foliar spray at 35 DAS $(154.71 \mathrm{~cm})$ at 80 days after sowing. The increase in plant height may be due to zinc plays a key role in metabolic activity and physiology reaction and acts as catalyzing enzymes, transformation of carbohydrates, chlorophyll content and protein synthesis Srinivasan (1992). The iron also had its role in starch formation, protein synthesis and synthesis of chlorophyll in plants. The increase in iron availability to plant might have stimulated the metabolic and enzymatic activities there by increasing the crop growth Trivedi et al., (2011). 


\section{Dry weight (g) per plant}

The analysed data presented shown significant variation among all other treatments. At 80 DAS significantly maximum plant dry weight (49.23g) were recorded in $0.5 \%$ foliar spray of $\mathrm{ZnSO}_{4}$ and $\mathrm{FeSO}_{4}$ at 35 and 55 DAS. Which was statistically with Soil application of $25 \mathrm{~kg} / \mathrm{ha}$ $\mathrm{ZnSO}_{4}+10 \mathrm{~kg} / \mathrm{ha} \mathrm{FeSO}_{4}(44.82 \mathrm{~g}$ ) and $0.5 \%$ $\mathrm{ZnSO}_{4}$ and $\mathrm{FeSO}_{4}$ foliar spray at 35 DAS (46.84g).

The increase in plant dry weight might be due to Zinc is the essential component of cellular growth, oxygen synthesis, differentiation and metabolism which results in vigorous growth of plants and extensive root system leading to increased growth of plants reported by Tamil et al., (2019) and Meena et al (2010). The foliar application of Zinc and Iron was found to be more effective due to its higher uptake efficiency compared to soil application as they helps in increased photosynthetic efficiency by delaying leaf senescence reported by Kuldeep et al., (2018).

\section{Yield and Yield Attributes}

The yield attributes like test weight, grain yield, stover yield was significantly affected by the different methods of application of zinc and iron at different stages were represented in Table 1.

\section{Test weight (g)}

The test weight showed significantly maximum test weight $(7.63 \mathrm{~g})$ were recorded in $0.5 \% \mathrm{ZnSO}_{4}+\mathrm{FeSO}_{4}$ foliar spray at 35 and 55 DAS which was statistically at par with $0.5 \% \mathrm{ZnSO}_{4}+\mathrm{FeSO}_{4}$ foliar spray at $35 \mathrm{DAS}$ $(7.2 \mathrm{~g})$. The reason for recording maximum test weight might due to the presence of Zinc in the foliar application stimulates the metabolic processes in seed Qudratullah et al., (2016) and Iron plays role in increasing supply of photosynthates to sink due to higher chlorophyll content and photosynthesis due to foliar sprays at different intervals during growing period of crop. The involvement of the sprayed zinc in enzyme activation, membrane integrity and starch utilization at early which enhanced accumulation of assimilates in the grains Abid et al., (2019).

\section{Grain yield (Kg/ha)}

The highest grain yield $(2327.37 \mathrm{~kg} / \mathrm{ha})$ was recorded significantly superior in $0.5 \%$ $\mathrm{ZnSO}_{4}$ and $0.5 \% \mathrm{FeSO}_{4}$ foliar sprayat 35 and 55 DAS over rest all other treatments. The results might be due to zinc and iron helps in vigorous root development, which promotes growth and development of plant leading to higher photosynthetic efficiency which resulted in better development of higher yield attributes Paramasivan et al., (2011).

The Zinc application might be attributed to its direct role on auxin production, which enables the plant to produce more dry matter and consequently enhanced the partitioning of photosynthates towards newly formed sink. Similar results were observed by Abdul et al., (2018) and Jyothi et al., (2015). Iron is involved in the reductive assimilation pathway of sulphur as ferredoxin is a reductant. Similar results were observed in Yadav and Chippa (2007) and Sareen and Sharma (2010).

\section{Stover yield (Kg/ha)}

Stover yield data showing that significant variation among all the treatments. The highest Stover yield was recorded significantly in $0.5 \% \mathrm{ZnSO}_{4}$ and $0.5 \% \mathrm{FeSO}_{4}$ foliar spray at 35 and 55 DAS which was at par with $0.5 \% \mathrm{ZnSO}_{4}$ and $0.5 \% \mathrm{FeSO}_{4}$ at 35 DAS. 
Table.1 Effect of zinc, iron and their methods of application on growth and yield attributes of pearlmillet

\begin{tabular}{|c|c|c|c|c|c|}
\hline Treatments & $\begin{array}{c}\text { Plant } \\
\text { height } \\
\text { (cm) at } 80 \\
\text { DAS }\end{array}$ & $\begin{array}{c}\text { Dry } \\
\text { weight at } \\
\text { 80 DAS }\end{array}$ & $\begin{array}{c}\text { Test } \\
\text { weight } \\
\text { (g) }\end{array}$ & $\begin{array}{c}\text { Grain yield } \\
(\mathrm{Kg} / \mathrm{ha})\end{array}$ & $\begin{array}{c}\text { Stover } \\
\text { yield } \\
\text { (Kg/ha) }\end{array}$ \\
\hline 1. Soil application of $25 \mathrm{~kg} / \mathrm{ha} \mathrm{ZnSO}_{4}$ & 134.68 & 42.55 & 5.8 & 1852 & 3878.11 \\
\hline 2. $0.5 \% \mathrm{ZnSO}_{4}$ foliar spray at $35 \mathrm{DAS}$ & 125.5 & 39.34 & 5.6 & 1743.21 & 3693.13 \\
\hline $\begin{array}{l}\text { 3. } 0.5 \% \mathrm{ZnSO}_{4} \text { foliar spray at } 35 \text { and } \\
55 \text { DAS }\end{array}$ & 137.76 & 43.92 & 6.33 & 1871.39 & 3799.44 \\
\hline 4.Soil application of $10 \mathrm{~kg} / \mathrm{ha} \mathrm{FeSO}_{4}$ & 123.19 & 39.14 & 5.97 & 1850.83 & 3754.99 \\
\hline 5.0.5\% $\mathrm{FeSO}_{4}$ foliar spray at $35 \mathrm{DAS}$ & 130.45 & 43.22 & 5.57 & 1785.25 & 3613.16 \\
\hline $\begin{array}{l}\text { 6. } 0.5 \% \mathrm{FeSO}_{4} \text { foliar spray at } 35 \text { and } \\
55 \mathrm{DAS}\end{array}$ & 135.43 & 42.99 & 6.4 & 1869.82 & 3665.58 \\
\hline $\begin{array}{l}\text { 7. Soil application of } 25 \mathrm{~kg} / \mathrm{ha} \mathrm{ZnSO}_{4} \\
+10 \mathrm{~kg} / \mathrm{ha} \mathrm{FeSO}_{4}\end{array}$ & 146.37 & 44.82 & 6.03 & 2064.2 & 4227.07 \\
\hline $\begin{array}{l}\text { 8. } 0.5 \% \mathrm{ZnSO}_{4} \text { and } \mathrm{FeSO}_{4} \text { foliar spray } \\
\text { at } 35 \text { DAS }\end{array}$ & 154.71 & 46.84 & 7.2 & 2119.57 & 4351.36 \\
\hline $\begin{array}{l}\text { 9. } 0.5 \% \mathrm{ZnSO}_{4} \text { and } \mathrm{FeSO}_{4} \text { foliar spray } \\
\text { at } 35 \text { and } 55 \text { DAS }\end{array}$ & 156.31 & 49.23 & 7.63 & 2327.37 & 4584.86 \\
\hline 10. Control (80-40-40 kg N-P-K/ha) & 123.19 & 36.39 & 5.27 & 1325.39 & 2706.51 \\
\hline $\operatorname{SEm}( \pm)$ & 2.7 & 1.60 & 0.26 & 32.16 & 83.65 \\
\hline $\mathrm{CD}(\mathrm{P}=\mathbf{0 . 0 5})$ & 8.02 & 4.76 & 0.76 & 95.56 & 248.54 \\
\hline
\end{tabular}

Zinc application improves the source and sinks relationship due to translocation of photosynthates which leads to increase of stover yield in Pearl millet Pradeep et al., (2014). Similar results were obtained by Abid et al., (2019) and Sareen and Sharma (2010).

More over quantity of nutrients absorbed due to soil application of Zinc and Iron may not be sufficient to meet the crop demands at seed formation stage. Supplementing the nutrients through foliage at flowering might have the better nutrient balance and there by regaining the photosynthetic efficiency of the plant at post anthesis period results in increased yield Inayat et al., (2015). Foliar application of Zinc and Iron at reproductive stages increased the grain and stover yield might be due to existence of favourable nutritional environment below and above ground Chowdhary (2014).
In conclusion the light of the above study, application of $0.5 \% \mathrm{ZnSO}_{4}$ and $\mathrm{FeSO}_{4}$ foliar spray at 35 and 55 DAS is more productive.

\section{Acknowledgement}

I express gratitude to my advisor Prof. (Dr.) Joy Dawson for constant support and guidance. I am indebted to Prof. (Dr.) Thomas Abraham, Dr. Vikram Singh and all the faculty members of SHUATS for inspiration

\section{References}

Abdul ShakoorKarrimi, Reddy, A.P.K, Babazoi, F and Tamana, K. 2018. Growth, Yield and Post-harvest soil available nutrients in sweet corn (Zea mays L.) as influenced by zinc and iron nutrition. Journal of Pharmacognosy and Phytochemistry 7(4):2372-2374. 
Abid khan, Zafar hayat, AsadAlikhan, Junaid Ahmad, Muhammad waseem Abbas, Haq Nawaz, Faran Ahmad and Kaleem Ahmad. 2019. Effect of foliar application of zinc and boron on growth and yield components of wheat. Agricultural Research and Technology. Open Access Journal. 2(1): 2471-6774.

Chowdhary, S.K. 2014. Effect of micronutrient fertilization and their methods of application on sorghum productivity. Thesis. Rajasthan Agricultural University, Bikaner.

Gomez, K.A., Gomez, A.A. 2010. Statistical procedures for agricultural research. $2^{\text {nd }}$ edn. Wiley India Pvt Ltd, India.

Inayatur Rahman., Aftab Afzal., Zafar Iqbal., Asmatullah., Ayeshanisar. 2015. Review of foliar feeding in various vegetables and cereal crop boosting growth and yield attributes. American, Eurasian Journal of Agricultural and Environmental Sciences. 15(1):74-77.

Jakhar, S.R., Singh, M. and Balai, C.M. 2006. Effect of farmyard manure, phosphorous and zinc levels on growth, yield, quality and economics of Pearlmillet (Pennisetumglaucum L.), Indian Journal of Agriculture Sciences, 76(1):58-61.

Jyothi, K. J., Ramana, A. V., Murthy, K. V. R. (2015). Nutrient uptake and postharvest soil nutrient status of Rabi Maize as effected by different nutrient levels. Journal of Soils and Crops, 25(2):253-258.

Kuldeep, Kumawat, P.K., Vipen, B., Sumeriya, H.K. and Kumar, V. 2018. Effect of Iron and Zinc nutrition on Growth Attributes and Yield of Chickpea (Cicer arietinum L.). International Journal of Current Microbiology and Applied Sciences, 7(8): 2837-2841.

Mortvedt, J. 2000. Efficient fertilizer use manual. National Fertilizer and Environmental Research. PP. 5-9.

Meena, L.R, Mann, J. S, Cheturvedi, O. H, Gill, S. C. 2010. Response of newly develop forage sorghum genotypes to zinc levels and Azospirillum under semi-arid conditions of Rajasthan. Forage Research. 36(3):128-132.

Pradeep kumar, Rajeev kumar, Simgh, S.K. and Anil Kumar. 2014. Effect of fertility on growth, yield and yield attributes of Pearlmillet (Pennisetum glaucum L.) under rainfed conditions. Research and Educational developmental Society. 2(2):89-93.

Paramasivam, M., Kumaresan, K.R., Malarvizhi, S and Velayudham, K. 2011. Effect of different levels of NPK and zinc on yield and nutrient uptake of hybrid maize in pilamedu and palaviduthi series of Tamil nadu, Madras Agricultural Journal. 98(1012): 334-338.

Qudratullah Shahab, Muhammad Afzal, Babar Hussain, Naeem Abbar, Qandeel Zehra, Altaf Hussain, Zubair Hussain, Ajaz Ali, Yawar Abbas. 2016. Effect of different methods of application on maize. International Journal of Agronomy and Agricultural Research, 9(3):66-73.

Rai Nitishkumar, Yadav, O.P. and Gupta, S.K. 2008. Pearlmillet: Genetic Improvement in Tolerance to Abiotic stresses. Improving Crop productivity in Sustainable Agriculture.

Sareen, H and Sharma, G. L, 2010. Effect of plant densities and fertilizer levels on growth and zinc uptake by extra early sorghum (Sorghum bicolor(L.) Moench). Annals of Agricultural Research. 31:32-37.

Singh, A.K and Kumar, P. 2009. Nutrient management in rainfed dryland agro ecosystem in the impending climate change scenario. Agril.Situ.in India. 
65:265-270.

Srinivasan, K. 1992. Effect of amendment and zinc level on the growth and yield of maize (Zea mays L.). Indian Journal of Agronomy, 37 (2): 246-249.

Tamil Amutham, G, Karthikeyan, R, Thavaprakash, $\mathrm{N}$ and Bharathi, $\mathrm{C}$. 2019. Agronomic bio-fortification with zinc on growth and yield of baby corn under irrigated condition. Journal of Pharmacognosy and Phytochemistry. 8(3):434-437.
Trivedi, A.K., Hemantaranjan, A. and Pandey, S.K., 2011. Iron application may improve growth and yield of soybean. Indian Journal of plant physiology, 16(3/4): 309-313.

Yadav, K. K., and Chippa, B. R., 2007. FYM, Gypsum and iron pyrites on fertility status of soil and yield of wheat with high RSC water. Journal of Indian Society of Soil Science. 5:324-329.

\section{How to cite this article:}

Ramasahayam Uday Kumar Reddy, Joy Dawson and Vidya Sagar, D. R. M. S. 2020. Effect of Zinc, Iron and their Methods of Application on Growth and Yield of Pearlmillet (Pennisetum glaucum L.). Int.J.Curr.Microbiol.App.Sci. 9(10): 1639-1644.

doi: https://doi.org/10.20546/ijcmas.2020.910.197 